\title{
The Arizona Easter Stabbing
}

James Gates

\section{I}

$t$ is no secret to anyone that prison can be the darkest of experiences. On

Easter Sunday morning in 1997, however, I was at least cautiously optimistic that even here in prison, even at a tough unit like Rynning at the Arizona State Prison Complex at Florence, it would be a good day. It was a beautiful spring morning in the Arizona desert, all the foliage in full bloom and the joy of Easter was clearly in the air. Breakfast passed uneventfully in our building, and everyone seemed in good spirits.

Easter is a day to experience, for Christians, the unbounded joy over the Resurrection of Christ. After returning from breakfast, I spent some prayer time alone in my cell. Later, I turned on the television and saw some live shots from Rome where Pope John Paul II was blessing thousands of the faithful at St. Peter's Square. Yes, it would be a good day. How could it not be? The image of the Pope stayed in my mind for the remainder of the morning, and was still there as we left to have lunch. Our building entered the dining hall at approximately 11:20 a.m. The meal consisted of sandwiches with coldcut meats, coleslaw, and Jello. I found an empty seat among some of the inmates and sat down.

The peace and the tranquillity of that Easter Sunday suddenly came to an abrupt halt at 11:30. A prisoner noisily dropped his tray and utensils on the far side of the room. While everyone looked over to see what had caused this, I heard a sharp popping sound directly behind me at an adjacent table. As I glanced up from my food, I saw small red droplets spraying through the air, hitting my clothes and food. My initial thought, actually, was that what I saw looked like Tabasco sauce. Time seemed to stand still for a moment, but as I turned toward the adjacent table I saw two prisoners, both with homemade shanks, furiously but diligently attempting to kill a third man. The assailants seemed to direct the majority of their blows to the neck of the victim and blood spurted out of him. One man yelled, "Die, die!!" as he continued the attack.

I managed to move away, shocked at how close I was to the incident. At the same time I noticed the lone female staff officer frantically radioing for assistance, powerless to stop what was happening. Various prisoners dived for cover in an effort to stay out of harm's way. Amazingly, after the two attackers finished pummelling the man with over 40 stab wounds and as backup staff arrived on the scene to restore order, both assailants calmly walked over 
to the female officer. They placed their weapons on the counter and put their hands behind their backs in anticipation of being handcuffed. Their victim, clinging to life, now lay in various puddles of his own blood on the floor.

The aftermath of this tragic event was equally surreal. Medical personnel rushed in to attend to the badly injured man. Soon they gingerly placed him in a wheelchair, with towels and bandages covering his wounds, and rushed him out to the complex medical unit. Meanwhile, a team of staff officers, having just arrived, led the two handcuffed prisoners out of the building to be interrogated. The entire Florence complex, consisting of several units, was immediately placed on administrative lockdown. Those of us already in the dining area, however, would remain there until staff completed videotaping the crime scene. It is safe to say that none of the prisoners managed to finish their lunch. It would have been an understatement to say that we had collectively lost our appetite. I recall looking down at my shirt and seeing the splotches of blood on it as well as on my right forearm, a clear reminder of how close I had been to the eye of this storm.

I was back in my cell shortly after noon. Sitting on my bed after removing the bloodstained clothing, I tried to hold my hands out in front of me, but I could not do so because they were trembling too much. Later, the word came via the grapevine that the motive for the stabbing had been a series of unpaid drug debts.

The fallout from the Easter Sunday brutality was, understandably, no cause for joy either. The Pinal County Attorney's Office charged the perpetrators with multiple counts of aggravated assault with a deadly weapon, and they eventually pled guilty. The resulting prison sentences were added consecutively to the time they were already serving. The victim slowly recovered his health after a lengthy stay in the hospital, where he had to be fed intravenously for a time. After all of the stitches were finally removed, he was sent to a remote, and hopefully more peaceful, minimum-security unit in Yuma, Arizona. The Department of Corrections, obviously hoping to avoid any further near deathexperiences in the dining hall, installed a state-of-the-art metal detector at the building's entrance. All prisoners coming to eat would now have to pass through this airpott-like device that would presumably weed out anyone carrying a weapon.

On a day when the worldwide Christian community celebrated death to life through the Resurrection of Christ, a group of Arizona prisoners came perilously close to experiencing life to death in a few short moments. The blessedness of 
Easter was suddenly snuffed out by two men venting their anger and hate in a profound way. I am certain that I will never forget what I witnessed that day. One fellow prisoner later remarked, "They could at least have waited until Monday." Sitting alone in my cell, my head in my hands, I firmly resolved not to let the horror of the moment overshadow the dazzling splendour of the day.

James Gates (\#88434) is incarcerated at Arizona State Prison Tucson, Box 24406 Santa Rita 3 B 18, Tucson, Arizona 85734, U.S.A. 